УДК [796.011/340.13]

ISSN (Ukrainian ed. Print) 1991-0177 ISSN (Ukrainian ed. Online) 1999-818X

2020, № 6(80), C.17-21

doi:10.15391/snsv.2020-6.003

\title{
Проблеми застосування законодавства у сфері фізичної культури та спорту
}

Марина Корольова
Харківська державна академія фізичної культури, Харків, Україна

Мета: охарактеризувати з позиції системного підходу проблеми застосування законодавства у сфері фізичної культури та спорту у сучасних умовах функціонування та запропонувати шляхи їх вирішення.

Матеріал і методи: для розв'язання поставлених завдань дослідження використовувався комплекс теоретичних методів: аналіз, порівняння, узагальнення, систематизація літературних джерел та документальних матеріалів, метод історизму, метод системного підходу.

Результати: проаналізовано систему спортивного законодавства в Україні, виявлено ряд проблем, зокрема: недосконалість системи взаємовідносин між державою та іншими суб'єктами сфери фізичної культури і спорту, невирішеність багатьох питань правового регулювання професійного спорту, неврегульованість на законодавчому рівні відносин меценатства та інвестицій у сфері фізичної культури і спорту та ін. Проаналізовано французький досвід кодифікації спортивного законодавства у контексті розробки пропозицій для вдосконалення спортивного законодавства України.

Висновки: наявність вище зазначених проблем удіючій системі спортивного законодавства України об'єктивно підтверджує необхідність систематизації спортивного законодавства, що забезпечить вирішення завдань державної політики щодо підвищення статусу сфери фізичної культури та спорту, ясності правозастосування, успішного розвитку галузі законодавства й спортивного права.

Ключові слова: законодавство, сфера фізичної культури та спорту, систематизація, кодифікація, спортивне право.

\section{Вступ}

Як відомо, фізична культура і спорт на сучасному етапі свого розвитку $є$ не тільки способом пітримки та зміцнення здоров'я населення, а й стилем життя сучасної успішної людини, зокрема саме спорт є вагомою частиною ринку, сферою державної політики. Адже для будь-якої держави досягнення, а особливо успіхи, на міжнародній спортивній арені $€$ не що інше, як спосіб заявити про своє місце у міжнародному політичному середовищі. До того ж масштабні міжнародні спортивні замагання за останні 10-15 років уже ні в кого не залишають сумнівів, що професійний спорт - це, перш за все, важлива частина світової політики, а не лише сфера суспільного життя [9].

Що стосується України, то останніми роками, на нашу думку, статус сфери фізичної культури і спорту значно підвищився. Доказом цьому є організація та проведення в Україні спортивних заходів глобального світового масштабу, серед яких чемпіонат Європи з футболу (2012), фінал Ліги чемпіонів з футболу (2018) та інші заходи. До того ж питання розвитку професійного, аматорського спорту, фізичного виховання дітей та молоді стали пріоритетними завданнями державної політики, про що йдеться у ряді законодавчих та підзаконних нормативно-правових документах [2, 4, 5, 6].
Аналіз останніх публікацій свідчить лише про епізодичне дослідження законодавства у сфері фізичної культури та спорту та відсутність системного підходу у вивченні цього питання. Науковий інтерес у сучасній вітчизняній літературі $[1,7]$ представляє формування галузі спортивного права в Україні, механізм державного управління фізичною культурою і спортом в Україні та організаційно-правові засади державного управління. У той же час проведений аналіз праць зарубіжних авторів $[10,12]$ свідчить, що спортивне право - це серйозна і самодостатня галузь права. Зарубіжні фахівці в області спортивного права досліджують тенденції розвитку «глобального» спортивного права, аналізують взаємоузгодженість міжнародного спортивного права і бізнесу у XXI столітті.

Мета дослідження - охарактеризувати з позиції системного підходу проблеми застосування законодавства у сфері фізичної культури та спорту у сучасних умовах функціонування та запропонувати шляхи їх вирішення.

\section{Матеріал і методи дослідження}

Для розв'язання поставлених завдань дослідження використовувався комплекс теоретичних методів: аналіз, порівняння, узагальнення, систематизація літера- 


\section{СЛОБОЖАНСЬКИЙ НАУКОВО-СПОРТИВНИЙ ВІСНИК}

турних джерел за темою дослідження, що дало змогу з'ясувати проблемне поле досліджень законодавства у сфері фізичної культури та спорту у сучасних умовах функціонуваня. Аналіз, порівняння, узагальнення, систематизація документальних матеріалів дозволили охарактеризувати особливості законодавства у сфері фізичної культури і спорту. Метод історизму дозволив виявити об'єктивні особливості спортивного права як нової галузі правової системи України. Застосування методу системного підходу дозволило визначити загальні тенденції та шляхи подальшого розвитку українського спортивного законодавства.

\section{Результати дослідження}

Правове регулювання є важливим чинником, який впливає на сферу фізичної культури і спорту та створює певні умови для її розвитку. У базових нормативно-програмних документах, які регулюють сферу фізичної культури і спорту в Україні, зокрема у Державній цільовій соціальній програмі розвитку фізичної культури і спорту до 2020 року [4], Стратегії формування сучасної системи олімпійської підготовки на період до 2020 року [6], а також у затвердженій постановою Кабінету міністірів України за № 1089 від 4 листопада 2020 року Стратегії розвиту фізичної культури і спорту до 2028 року [5] визначаються ряд проблем та причини їх виникнення за напрямами державної політики у сфері фізичної культури і спорту.

Однією із ключових проблем, як вказується у цій нещодавно прийнятій Стратегії, є недосконала система взаємовідносин між державою та іншими суб'єктами сфери, що перешкоджає популяризації фізичної культури і спорту. Причинами виникнення проблеми є неврегульованість на законодавчому рівні механізму здійснення контролю за кваліфікацією кадрів у фітнес-індустрії, відносин меценатства та інвестицій у сфері фізичної культури і спорту, недостатня кількість інформаційно-соціальних кампаній, спрямованих на популяризацію спорту ті ін. [5]. Ми переконані, що розв'язання вище зазначеної проблеми можливе лише через удосконалення нормативно-правової бази сфери фізичної культури і спорту.

Ключовим нормативно-правовим актом у системі спортивного законодавства є Закон України «Про фізичну культуру та спорт» від 24 грудня 1993 року. Постійно йде робота щодо удосконалення його положень, адже зміни в нього вносились щорічно, починаючи з 1999 року. У 2009 році цей Закон був прийнятий Верховною Радою у новій редакції, але й після цього він вже неодноразово змінювався та доповнювався. Прийняття Закону в оновленій редакції створює для нашої держави нов можливості для виконання поставлених завдань, але, на жаль, не вирішує всі проблеми, які виникають у сфері фізичної культури і спорту [2].

Особливої уваги заслуговують зміни, внесені до Закону від 02.06.2020 року. Так, розділ II «Суб’єкти сфери фізичної культури і спорту» доповнено статтею 211 «Спортивна студентська спілка України» та статтею 212 «Українська федерація учнівського спорту». Спортивна студентська спілка України та Українська федерація учнівського спорту - це громадські об'єднання фізкультурно-спортивної спрямованості, які мають всеукраїнський статус відповідно до закону та визнані Міжнародною федерацією університетського спорту та Міжнарод- ною федерацією учнівського спорту відповідно [2]. Адже це $є$ нетиповою ситуацією для України, коли громадські організації вносяться до законодавчого документу та отримують окрему бюджетну графу фінансування. Ці зміни до Закону, безперечно, сприятимуть розвитку фізкультурно-спортивного руху серед учнівської та студентської молоді, формуванню в учнів та студентів сталих традицій до занять фізичними вправами та ведення здорового способу життя тощо.

Заслуговує на увагу також питання правового регулювання професійного спорту. У ст. 38 Закону України «Про фізичну культуру та спорт» йдеться про те, що держава створює умови для подальшого розвитку професійного спорту на комерційних засадах. На законодавчому рівні регулюються економічні та трудові відносини у професійному спорті, розробляються заходи щодо захисту інтересів спортсменів-професіоналів. Проте, не зважаючи на задекларовані наміри держави врегулювати відносини у сфері професійного спорту шляхом прийняття відповідного законодавства, а саме: у 2014 році Національної доктрини розвитку фізичної культури і спорту, у 2009 році - Стратегії формування сучасної системи олімпійської підготовки на період до 2020 року, нині багато питань у цій площині залишаються або неврегульованими, або такими, що вимагають удосконалення, а чинність вище зазначених документів уже втратилась.

Гострою проблемою сфери фізичної культури і спорту є також фінансування. Адже, з одного боку, фізична культура і спорт фінансуються з державного та місцевих бюджетів за «залишковим принципом» і дуже потребує залучення позабюджетних джерел фінансування, а 3 іншого боку - неврегульованість на законодавчому рівні відносин меценатства та інвестицій у сфері фізичної культури і спорту, вимагають створити сприятливі та чіткі законодавчі умови для доброчинної допомоги з боку небайдужих меценатів. Однак, до сьогодні немає прийнятого окремого нормативно-правового акту, присвяченого саме фінансовому забезпеченню сфери фізичної культури і спорту в Україні, а існуючі законодавчі норми, присвячені благодійній діяльності, не відповідають потребам цієї сфері. Наприклад, існує потреба законодавчо визначити окремо для цієї сфери: осіб, що можуть бути меценатами, одержувачами, кінцевими вигодонабувачами меценатської допомоги; принципи, можливі напрямки меценатства; питання укладення договорів про надання меценатської допомоги; окремі питання діяльності профільного центрального органу виконавчої влади, що відповідає за сферу фізичної культури та спорту. На вирішення цих питань розроблено та подано до розгляду Верховною Радою України законопроєкт «Про меценатство у сфері фізичної культури та спорту», який покликаний сприяти меценатству в сфері фізичної культури та спорту [3]

Аналіз даного законопроєкту показав, що він визначає поняття «меценатства» саме застосовуючи його до сфери фізичної культури та спорту. Зокрема автор законопроєкту трактує дане поняття як «недержавну добровільну безоплатну діяльність фізичних та юридичних осіб, що не спрямована на отримання доходу». Крім того, у даному законопроєкті зазначені навіть принципи меценатства. У законопроєкті визначено також коло одержувачів меценатської допомоги. Це може бути фізична особа, або неприбуткова організація, або тери- 
торіальна громада. Окреслено напрямки використання меценатської допомоги [3]

До сильних сторін запропонованого законопроєкту відносяться також положення щодо врегулювання питання укладення договору про надання меценатської допомоги. Зокрема, передбачається обов'язковість додержання письмової форми договору, визначаються також умови укладення договору про надання меценатської допомоги. На особливу увагу, на нашу думку, заслуговує положення законопроєкту щодо прав мецената. Адже практика співпраці бізнес-структур та фізкультурно-спортивних організацій показує, що саме відсутність можливості з боку пожертвувача здійснювати контроль за використанням його меценатської допомоги є причиною виникнення більшості конфліктних ситуацій. Тому дуже важливим $€$ те, що відповідно до положень даного законопроєкту, який дозволяє меценату скористатись деякими правами пожертвувача, передбаченими Цивільним кодексом України. До таких прав відноситься: право здійснювати контроль за використанням меценатської допомоги відповідно до мети, зазначеної у договорі; право отримати законодавчу гарантію щодо можливості використання такої допомоги за іншим призначенням лише за його, мецената, згодою, а також щодо права вимагати розірвання договору, якщо зазначена допомога використовується не за призначенням. На практиці реалізацію даних прав мецената ми вбачаємо у створенні наглядової ради при фізкультурно-спортивній організації, чи будь-якій організації, яка отримує благодійну допомогу, та призначенні головою цієї ради саме мецената з тим, щоб він мав можливість здійснювати безпосередній контроль за фінансовою політикою та цільовим використанням наданих ним коштів у даній організації [3].

Запропонований законопроєкт створює умови для здійснення громадського та державного контролю 3 тим, щоб не було зловживань при здійсненні меценатства в сфері фізичної культури та спорту. Це положення забезпечуватиметься наступними умовами: меценат зобов'язаний буде повідомити Міністерство молоді та спорту України про укладення договору про надання меценатської допомоги, надавши копію такого договору, внесені до нього зміни, розірвання такого договору. Наступною умовою $є$ обов'язкове оприлюднення у мережі Інтернет на офіційному веб-сайті зазначеного органу влади істотних умов договору. Міністерство молоді та спорту також має право у порядку та у випадках, встановлених Урядом, здійснювати перевірку використання за призначенням меценатської допомоги.

У разі прийняття даного законопроєкту реалізація його положень не потребуватиме внесення змін до інших законів. Однак доцільно прийняти також необхідні зміни до Податкового кодексу України щодо податкового стимулювання здійснення меценатства у сфері фізичної культури та спорту, тобто надання податкових пільг меценатам. Важливо, що прийняття законопроєкту не призведе до зміни показників державного та місцевих бюджетів, «при цьому меценати фактично будуть матеріально забезпечувати реалізацію тих цілей та завдань у сфері фізичної культури та спорту, реалізація яких мала би здійснюватись за рахунок державного та місцевого бюджетів» [3]. Адже із практики розвитку сфери фізичної культури і спорту ми знаємо, що доходів цих бюдже- тів постійно бракує для того, щоб передбачати витрати в обсягах, які би в повній мірі відповідали потребам сфери фізичної культури та спорту.

\section{Висновки / Дискусія}

Наявність вище зазначених проблем у діючій системі спортивного законодавства України об'єктивно підтверджує необхідність систематизації законодавства, яка забезпечить належне праворозуміння і правозастосування в цій сфері. Розглядаючи відомі види систематизації, необхідно відзначити, що вони формують сувору ієрархію, на верхньому щаблі якої знаходиться кодифікація.

У праці фахівців права [9] підкреслюється, що нині в Україні діє понад 20 кодексів, а процес кодифікації нормативно-правових актів триває у напрямку як переробки діючих кодексів, так і розробки нових. Автори зазначають, що дослідниками розглядаються проблеми розробки транспортного, трудового, екологічного кодексів україни тощо. Ми погоджуємось із думкою авторів, що питання про кодифікацію актуальне і для розвитку спортивного права та $є$ оптимальним шляхом вирішення існуючих проблем законодавства у сфері фізичної культури та спорту на сучасному етапі.

На нашу думку, головним та найбільш очевидним аргументом на користь кодифікації є кодифікація законодавства у сфері фізичної культури і спорту, яка спостерігається у ряді зарубіжних країн (США, Бразилія, Франція).

На особливу увагу заслуговує Франція, де діє Спортивний кодекс, який було розроблено у 2004 році та прийнято у 2006 році. Як і наше вітчизняне право, французьке право відноситься до континентальної правової сім'ї. Тому аналіз французького досвіду кодифікації спортивного законодавства $€$ надзвичайно важливим у контексті розробки пропозицій для вдосконалення спортивного законодавства України. Варто зазначити, що даний Кодекс «призначався для поліпшення розуміння і доступності спортивного законодавства, власне, у тих же цілях сьогодні виникає необхідність і розвитку українського спортивного законодавства [13].

Коротко характеризуючи Спортивний кодекс Франції, необхідно зазначити, що він складається із 4 книг, кожна із яких присвячена окремому аспекту спортивного права [11]. Перша книга присвячена організації заходів 3 фізичної клуьтури і спорту. Друга книга присвячена учасникам спортивних замагань, зокрема спортсменам, арбітрам, тренерам, викладачам, функціонерам. Третя книга присвячена різним видам спортивних практик, безпеці та гігієні спорту, організації та управлінню спортивними подіями. Четверта книга присвячена фінансуванню спорту і застосуванню законодавства в правовідносинах, що виникають в «заморських спортивних комунах».

Варто зазначити, що Спортивний кодекс Франції задав суттєвого імпульсу для розвитку французького спорту і створив реальні умови для ефективної боротьби з корупцією. Французький досвід кодифікації спортивного права є яскравим прикладом того, як в ході систематизації спортивного законодавства вирішуються завдання стосовно підвищення статусу фізичної культури та спорту, ясності правозастосування, закладається вектор для успішного розитку галузі законодавства й спортивного права. 


\section{СЛОБОЖАНСЬКИЙ НАУКОВО-СПОРТИВНИЙ ВІСНИК}

Отже, нами підтверджено дані дослідників [1, 9], та дані наших попередніх досліджень $[7,8]$ щодо існування проблеми законодавства у сфері фізичної культури та спорту у сучасних умовах функціонуваня в Україні та необхідності удосконалення системи норм у галузі спортивних правовідносин на законодавчому рівні, зокрема створення відповідних кодифікованих актів.
Перспективи подальших досліджень пов'язуємо з необхідністю розробки та обґрунтування конкретних заходів щодо удосконалення законодавства у сфері фізичної культури і спорту, враховуючи позитивний зарубіжний досвід правового регулювання спортивної діяльності.

Конфлікт інтересів. Автори заявляють, що немає конфлікту інтересів, який може сприйматися як такий, що може завдати шкоди неупередженості статті.

Джерела фінансування. Ця стаття не отримала фінансової підтримки від державної, громадської або комерційної організації.

\section{Список посилань}

1. Гаро Г. О., Кушнір О. О. (2017), «Спортивне право: огляд національного законодавства і міжнародних стандартів», Господарське право та процес. URL: https://protocol.ua/ua/sportivne_pravo_oglyad_natsionalnogo_zakonodavstva_i_mignarodnih_ standartiv/ (дата звернення: 05.11.2020).

2. Закон України «Про фізичну культуру і спорт». Верховна Рада України. Законодавство України: офіційний веб-сайт. URL: http://zakon.rada.gov.ua/laws/show/ru/3808-12 (дата звернення: 12.10.2020).

3. Пояснювальна записка до проекту Закону України від 01.08.2017 № 6770-1 «Про меценатство у сфері фізичної культури та спорту». LIGA 360: офіційний веб-сайт Ліга-Закон. URL: https://ips.ligazakon.net/document/GH5821AA (дата звернення: 22.11.2020).

4. Про затвердження Державної цільової соціальної програми розвитку фізичної культури і спорту на період до 2020 року. Верховна Рада України. Законодавство України: офіційний веб-сайт. URL: https://zakon.rada.gov.ua/laws/show/115-2017\%D0\%BF\#Text (дата звернення: 02.10.2020).

5. Про затвердження Стратегії розвитку фізичної культури і спорту на період до 2028 року. Верховна Рада України. Законодавство України: офіційний веб-сайт. URL: https://zakon.rada.gov.ua/laws/show/1089-2020-\%D0\%BF\#Text (дата звернення: 12.09.2020).

6. Про схвалення Стратегії формування сучасної системи олімпійської підготовки на період до 2020 року. Верховна Рада України. Законодавство України: офіційний веб-сайт. URL: https://zakon.rada.gov.ua/laws/show/592-2009-\%D1\%80\#Text (дата звернення: 22.09.2020)

7. Саннікова М.В. (2018), «Онтологія розвитку галузі спортивного права», Фізичне виховання, спорт і культура здоров'я у сучасному суспільстві, № 4(44). С. 3 - 9 .

8. Саннікова М.В. (2019), «Актуальні проблеми правового регулювання та законодавства у сфері фізичної культури і спорту в Україні», Слобожанський науково-спортивний вісник, №3 (71), С. 37-42.

9. Харитонов Є. О. Спортивне право: актуальні проблеми. Одеса: Юридична література, 2018. 240 с.

10. Hartley D. H. (2005). «International Sports Law and Business in the 21st Century»? The Entertainment and Sports Law Journal, No. 3(1). URL: https://www.entsportslawjournal.com/articles/10.16997/eslj.126/ (дата звернення: 3.06.2019).

11. Julien L. (2015), Les institutions sportives en France (introduction an droit du sport), Publications Doc Du Juriste. URL:https:// www.doc-du-juriste.com/droit-prive-et-contrat/droit-autres-branches/cours-de-professeur/institutions-sportives-franceintroduction-droit-sport-479549.html(дата звернення: 2.10.2020).

12. Kolev B. (2008), «Lex sportive and Lex Mercatoria», The International Sports Law Journal, No. 1-2.

13. Schut P., Collinet C. (2016), «French sports policies for young people: fragmentation and coordination modes», International Journal of Sport Policy and Politics, No. 1, pp. 117-134.

Стаття надійшла до редакції: 20.11.2020 p.

Опубліковано: 21.12.2020 p.

Аннотация. Марина Королёва. Проблемы применения законодательства в сфере физической культуры и спорта. Цель: охарактеризовать с позиции системного подхода проблемы применения законодательства в сфере физической культуры и спорта в современных условиях функционирования и предложить пути их решения. Материал и методы: для решения поставленных задач исследования использовался комплекс теоретических методов: анализ, сравнение, обобщение, систематизация литературных источников и документальных материалов, метод историзма, метод системного подхода Результаты: проанализирована система спортивного законодательства в Украине, выявлен ряд проблем, в частности: несовершенство системы взаимоотношений между государством и другими субъектами сферы физической культуры и спорта, нерешённость многих вопросов правового регулирования профессионального спорта, неурегулированность на законодательном уровне отношений меценатства и инвестиций в сфере физической культуры и спорта и др. Проанализирован французский опыт кодификации спортивного законодательства в контексте разработки предложений по совершенствованию спортивного законодательства Украины. Выводы: наличие вышеуказанных проблем в действующей системе спортивного законодательства Украины объективно подтверждает необходимость систематизации спортивного законодательства, что обеспечит решение задач государственной политики по повышению статуса сферы физической культуры и спорта, ясности правоприменения, успешного развития области законодательства и спортивного права.

Ключевые слова: законодательство, сфера физической культуры и спорта, систематизация, кодификация, спортивное право. 
Abstract. Maryna Korolova. Problems of the application of legislation in the field of physical culture and sports. Purpose: to characterize from the position of a systematic approach the problems of applying legislation in the field of physical culture and sports in modern conditions of functioning and to propose ways to solve them. Material and methods: to solve the set research tasks, a set of theoretical methods was used: analysis, comparison, generalization, systematization of literary sources and documentary materials, the method of historicism, the method of a systematic approach. Results: the system of sports legislation in Ukraine was analyzed, a number of problems were identified, in particular: imperfection of the system of relations between the state and other subjects of the sphere of physical culture and sports, unresolved issues of legal regulation of professional sports, unsettled relations between patronage and investments in the field of physical culture at the legislative level and sports, etc. The French experience of codification of sports legislation in the context of developing proposals for improving the sports legislation of Ukraine is analyzed. Conclusions: the presence of the above problems in the current system of sports legislation of Ukraine objectively confirms the need to systematize sports legislation, which will ensure the solution of the tasks of state policy to improve the status of the sphere of physical culture and sports, the clarity of law enforcement, the successful development of the field of legislation and sports law.

Keywords: legislation, the sphere of physical culture and sports, systematization, codification, sports law.

\section{References}

1. Haro, H. O., Kushnir, O. O. (2017), «Sports Law: a review of national legislation and international standards», Hospodarske pravo ta protses. URL: https://protocol.ua/ua/sportivne_pravo_oglyad_natsionalnogo_zakonodavstva_i_mignarodnih_standartiv/ (in Ukr.).

2. Zakon Ukrainy «Pro fizychnu kulturu i sport» [Law of Ukraine "On Physical Culture and Sports"]. Verkhovna Rada Ukrainy. Zakonodavstvo Ukrainy: ofitsiinyi veb-sait.URL: http://zakon.rada.gov.ua/laws/show/ru/3808-12 (in Ukr.).

3. Poiasniuvalna zapyska do proektu Zakonu Ukrainy vid 01.08.2017 № 6770-1 «Pro metsenatstvo u sferi fizychnoi kultury ta sportu» [Explanatory note to the draft Law of Ukraine dated 01.08.2017 № 6770-1 "On patronage in the field of physical culture and sports"]. LIGA 360: ofitsiinyi veb-sait Liha-Zakon.URL: https://ips.ligazakon.net/document/GH5821AA (in Ukr.).

4. Pro zatverdzhennia Derzhavnoi tsilovoi sotsialnoi prohramy rozvytku fizychnoi kultury i sportu na period do 2020 roku [About the statement of the State target social program of development of physical culture and sports for the period till 2020]. Verkhovna Rada Ukrainy. Zakonodavstvo Ukrainy: ofitsiinyi veb-sait. URL: https://zakon.rada.gov.ua/laws/show/115-2017-\%D0\%BF\#Text (in Ukr.).

5. Pro zatverdzhennia Stratehii rozvytku fizychnoi kultury i sportu na period do 2028 roku [On approval of the Strategy for the development of physical culture and sports for the period up to 2028]. Verkhovna Rada Ukrainy. Zakonodavstvo Ukrainy: ofitsiinyi vebsait. URL: https://zakon.rada.gov.ua/laws/show/1089-2020-\%D0\%BF\#Text (in Ukr.).

6. Pro skhvalennia Stratehii formuvannia suchasnoi systemy olimpiiskoi pidhotovky na period do 2020 roku [On approval of the Strategy for the formation of a modern system of Olympic training for the period up to 2020]. Verkhovna Rada Ukrainy. Zakonodavstvo Ukrainy: ofitsiinyi veb-sait. URL: https://zakon.rada.gov.ua/laws/show/592-2009-\%D1\%80\#Text (in Ukr.).

7. Sannikova, M. V. (2018), "Ontology of sports law development", Fizychne vykhovannia, sport i kultura zdorovia u suchasnomu suspilstvi, No. 4(44). pp. 3 - 9. (in Ukr.).

8. Sannikova, M. V. (2019), "Actual problems of legal regulation and legislation in the field of physical culture and sports in Ukraine", Slobozhanskyi naukovo-sportyvnyi visnyk, No. 3 (71), pp. 37-42. (in Ukr.).

9. Kharytonov, Ye. O. Sportyvne pravo: aktualni problem [Sports law: current issues]. Odesa: Yurydychna literatura, 2018. 240 p. (in Ukr.).

10. Hartley, D. H. (2005). "International Sports Law and Business in the 21st Century"? The Entertainment and Sports Law Journal, No. 3(1). URL: https://www.entsportslawjournal.com/articles/10.16997/eslj.126/ (in Eng.).

11. Julien, L. (2015), Les institutions sportives en France (introduction an droit du sport), Publications Doc Du Juriste. URL:https://www.doc-du-juriste.com/droit-prive-et-contrat/droit-autres-branches/cours-de-professeur/institutions-sportives-franceintroduction-droit-sport-479549.html (in Eng.).

12. Kolev, B. (2008), "Lex sportive and Lex Mercatoria", The International Sports Law Journal, No. 1-2. (in Eng.).

13. Schut, P., Collinet, C. (2016), "French sports policies for young people: fragmentation and coordination modes", International Journal of Sport Policy and Politics, No. 1, pp. 117-134 (in Eng.).

Received: 20.11.2020.

Published: 21.12.2020.

\section{Відомості про авторів / Information about the Authors}

Корольова Марина Вікторівна: к.ю.н., Харківська державна академія фізичної культури: вул. Клочківська 99, м. Харків, 61058, Україна.

Королёва Марина Викторовна: к.ю.н., Харьковская государственная академия физической культуры: ул. Клочковская 99, г. Харьков, 61058, Украина.

Maryna Korolova: Candidate of Juridical Sciences (Ph.D), Kharkiv State Academy of Physical Culture: 99 Klochkivska Str., Kharkiv, 61058, Ukraine.

ORCID.ORG/0000-0003-2931-2190

E-mail: m.korolova@khdafk.com 